Published December 2018

EKONOMIKAWAN : Jurnal IImu Ekonomi dan Studi Pembangunan

ISSN : 1693-7600 (Print), ISSN : 2598-0157 (Online), http://jurnal.umsu.ac.Id/Index.php/ekawan

\title{
Analisis Kinerja Pengelolaan Pendapatan Asli Daerah (PAD) di Kabupaten Padang Pariaman, Sumatera Barat
}

\author{
Tiara Resti Adha ${ }^{1 *}$,Dhea Stevenie ${ }^{2}$, Syafira Wahyuni $^{3}$, Weriantoni $^{4}$ \\ Program Studi Ilmu Ekonomi Universitas Andalas \\ Jalan Universitas Andalas, Limau Manis, Pauh, Limau Manis, Pauh, \\ Kota Padang, Sumatera Barat 25163 \\ *e-mail: tiararestiadha178@gmail.com
}

\begin{abstract}
ABSTRAK
Analisis Kinerja Keuangan Pada Dinas Pendapatan Pengelolaan Keuangan Dan Aset Daerah Kabupaten Padang Pariaman Tahun 2011-2015.Tujuan dari penelitian ini adalah untuk menganalisis Kinerja Keuangan Kabupaten Padang Pariaman jika dilihat dari: (1) peningkatan rill pendapatan asli daerah. (2) Efektivitas Pendapatan Daerah (3) Elastisitas Pendapatan Daerah (4) Rasio Pajak Daerah. Data yang digunakan adalah Realisasi Anggaran Pendapatan dan Belanja Daerah Kabupaten Padang Pariaman tahun anggaran 2011 sampai dengan 2015. Teknik pengumpulan data adalah dokumentasi. Metode analisis data adalah melakukan perhitungan kinerja pengelolaan Pendapat Asli Daerah. Hasil Penelitian menunjukkan bahwa: (1) Kinerja Keuangan Kabupaten Padang Pariaman dilihat dari peningkatan rill pendapatan asli daerah untuk tahun 2011 sampai 2015 meningkat dari tahun ke tahun,walaupun pada tahun 2015 mengalami penurunan.(2) dilihat dari efektivitas pendapatan asli daerah sangat efektif dari tahun ke tahun, karena melebihi dari 100\%.(3) dilihat dari elastisitas Pendapatan Asli Daerah, kabupatan Padang Pariaman kinerja pengelolaan PAD dapat dikatakan elastis karena nilai nya > 1.(4) dilihat dari rasio pajak daerah, kabupaten Padang Pariaman dalam pengelolaan keuangan nya dapat dikatakan stabil, karena angka menunjukkan 2011 sampai 2014 sebesar 15\% dan tahun 2016 bergeser menjadi $16 \%$.
\end{abstract}

Kata Kunci : Kinerja Pengelolaan PAD, Peningkatan rill PAD, Efektivitas pengelolaan PAD, Elastisitas Pengelolaan PAD, Rasio Pajak Daerah 


\title{
Analysis of Performance of Regional Original Revenue Management $(P A D)$ in Padang Pariaman District, West Sumatra
}

\begin{abstract}
Financial Performance Analysis of the Regional Financial and Asset Management Revenue Service of Padang Pariaman Regency in 2011-2015. The purpose of this study was to analyze the Financial Performance of Padang Pariaman Regency when viewed from: (1) increasing the real income level of the region. (2) Effectiveness of Regional Revenues (3) Regional Income Elasticity (4) Regional Tax Ratio. The data used is the Realization of the Regional Revenue and Expenditure Budget of Kabupaten Padang Pariaman in the fiscal year 2011 to 2015. The technique of collecting data is documentation. The method of data analysis is calculating the performance of the Regional Original Opinion management. The results of the study show that: (1) the financial performance of Kabupaten Padang Pariaman seen from the increase in real regional revenue for 2011 to 2015 increased from year to year, even though in 2015 it decreased (2) seen from the effectiveness of the original region's very effective income from year to year, because it exceeds 100\%. (3) judging from the Regional Original Income elasticity, kabupaten Padang Pariaman Performance Management of PAD can be said to be elastic because of its value > 1. (4) seen from the regional tax ratio, Kabupaten Padang Pariaman in financial management it can be said to be stable, because the figures from 2011 to 2014 amounted to $15 \%$ and 2016 shifted to $16 \%$.
\end{abstract}

Keywords: Performance of PAD Management, Real PAD Improvement, Effectiveness PAD management, PAD Elasticity Management, Tax Ratio Area 


\section{PENDAHULUAN}

Titik awal dimulainya otonomi daerah adalah Undang-Undang (UU) No. 32 Tahun 2004 tentang Pemerintah Daerah (Pemda) dan Undang-Undang No. 33 Tahun 2004 tentang Perimbangan Keuangan antara Pemerintah Pusat dan Daerah. Otonomi daerah adalah pemberdayaan daerah dalam pembuatan keputusan daerah yang lebih leluasa untuk mengelola sumber daya yang ada sesuai dengan keputusan dan prioritas serta potensi daerah. Diperlukannya kewenangan yang luas dan beratnggungjawab secara proporsional untuk mendukung penyelenggaraan otonomi daerah tersebut, yang diwujudkan dengan pengaturan, pembagian dan pemanfaatan sumber daya nasional yang berkeadilan, serta perimbangan keuangan pemerintah pusat dan pemerintah daerah.

Dengan adanya Undang-Undang tersebut telah memberi kewenangan yang lebih luas kepada pemerintah daerah tingkat kabupaten untuk menyelenggarakan semua urusan pemerintah mulai dari perencanaan potensi yang dimiliki dalam rangka membangun dan mengembangkan, pengendalian dan evaluasi, sehingga mendorong pemerintah daerah untuk lebih memberdayakan semua daerahnya. Jika Dilihat dari segi ekonomi, ada dua pengaruh nyata yang diharapakan dari pelaksanaan otonomi daerah yaitu : pertama ; mendorong peningkatan partisipasi, prakasa, dan kreativitas masyarakat dalam pembangunan serta pemerataan hasil-hasil pembangunan di seluruh daerah dengan memanfaatkan sumber daya dan potensi yang tersedia di masing-masing daerah. Kedua; memperbaiki alokasi faktor-faktor produksi dengan mendesetralisasikan pengambilan keputusan ke daerah.

Munculnya perbaikan pada alokasi faktor-faktor produksi itu disebabkan adanya efisiensi teknis dalam pengambilan keputusan, tidak perlu meminta persetujuan dari pemerintah pusat, dan efisiensi ekonomis yang berupa terciptanya alokasi faktor-faktor produksi yang sesuai pilihan masyarakat dengan daerah pengambilan keputusan. Anggaran Pendapatan dan Belanja Daerah (APBD) merupakan alat kebijakan yang utama bagi Pemerintah Daerah. Anggaran Pendapatan dan Belanja Daerah (APBD) mendukung posisi sentral dalam upaya pengembangan kapabilitas dan efektifitas Pemda.

Anggaran Pendapatan dan Belanja Daerah (APBD) dapat digunakan sebagai instrumen untuk menetapkan besar kecilnya pendapatan dan pengeluaran, membantu pengambilan keputusan dan pencapaian pembangunan, kebijakan pengeluaran di masamasa yang akan datang, sumber pengembangan ukuran-ukuran standar untuk evaluasi kinerja, sebagai alat untuk memotivasi para pegawai dan koordinasi bagi semua aktivitas dari berbagai unit kerja. Pengelolaan keuangan daerah membutuhkan sumber daya manusia yang handal dan didukung oleh kemampuan keuangan daerah yang memadai.

Tingkat kemampuan daerah dapat diukur dari besarnya penerimaan daerah khususnya Pendapatan Asli Daerah. Pendapatan Asli Daerah berdasarkan Undang-Undang Nomor 33 Tahun 2004 tentang Perimbangan Keuangan Antara Pusat dan Daerah Pasal 1 angka 18 bahwa "Pendapatan asli daerah, selanjutnya disebut PAD adalah pendapatan yang diperoleh daerah yang dipungut berdasarkan peraturan daerah sesuai dengan peraturan perundang-undangan".

Di kabupaten padang pariaman pendapatan asli daerahnya meningkat dari tahun 2010 sampai dengan tahun 2015 dilihat dari tabel sebagai berikut : 


\section{Published December 2018}

EKONOMIKAWAN : Jurnal Ilmu Ekonomi dan Studi Pembangunan

ISSN : 1693-7600 (Print), ISSN : 2598-0157 (Online), http://jurnal.umsu.ac.id/index.php/ekawan

Tabel 1

Pendapatan Asli Daerah Kabupaten Padang Pariaman

\begin{tabular}{|c|c|}
\hline Tahun & PAD \\
\hline 2010 & 24706049065 \\
\hline 2011 & 27073433254 \\
\hline 2012 & 31287086222 \\
\hline 2013 & 42619199169 \\
\hline 2014 & 62821048940 \\
\hline 2015 & 73095148984 \\
\hline
\end{tabular}

Sumber : Laporan Keterangan Pertanggungjawaban (LKPJ)

Pemerintah Daerah Kabupaten Padang Pariaman, 2016.

Dengan meningkatnya pendapatan asli daerah di kabupatan Padang Pariaman, maka Penulis ingin mengetahui apa saja yang menjadi penyebab pertumbuhan PAD, serta bagaimana kinerja pengelolaan PAD di Kabupaten Padang Pariaman.

\section{KAJIAN PUSTAKA}

Menurut Warsito (2001:128) Pendapatan Asli Daerah "Pendapatan asli daerah (PAD) adalah pendapatan yang bersumber dan dipungut sendiri oleh pemerintah daerah. Sumber PAD terdiri dari: pajak daerah, restribusi daerah, laba dari badan usaha milik daerah (BUMD), dan pendapatan asli daerah lainnya yang sah". Menurut Herlina Rahman (2005:38) Pendapatan asli daerah adalah pendapatan daerah yang bersumber dari hasil pajak daerah, hasil distribusi hasil pengelolaan kekayaan daerah yang dipisahkan dan lainlain pendapatan asli daerah yang sah dalam menggali pendanaan dalam pelaksanaan otonomi daerah sebagai perwujudan asas desentralisasi.

Arah kebijakan keuangan daerah adalah untuk meningkatkan pendapatan asli daerah sebagai sumber utama pendapatan daerah yang dapat dipergunakan oleh daerah dalam melaksanakan pemerintahan dan pembangunan daerah sesuai dengan kebutuhannya guna memperkecil ketergantungan dalam mendapatkan dana. Pendapatan asli daerah itu sendiri, dianggap sebagai alternatif untuk memperoleh tambahan dana yang dapat digunakan untuk berbagai kebutuhan pengeluaran yang ditentukan oleh daerah sendiri khususnya pengeluaran rutin. Oleh karena itu peningkatan pendapatan tersebut merupakan hal yang dikehendaki setiap daerah (Mamesa, 1995:30).

Pendapatan Asli Daerah (PAD) merupakan pendapatan daerah yang bersumber dari hasil pajak daerah, hasil retribusi Daerah, hasil pengelolaan kekayaan daerah yang dipisahkan, dan lain-lain pendapatan asli daerah yang sah, yang bertujuan untuk memberikan keleluasaan kepada daerah dalam menggali pendanaan dalam pelaksanaan otonomi daerah sebagai mewujudan asas desentralisasi. (Penjelasan UU No.33 Tahun 2004).

\section{METODE}

Pendeketan penelitian yang digunakan dalam penelitian ini adalah pendekatan deskriptif, yaitu suatu metode analisis dengan cara mendeskripsikan atau menggambarkan data yang telah terkumpul sehingga dapat memberikan kesimpulan mengenai kinerja PAD di kecamatan Padang Pariaman dari tahun 2010-2015. 
1. Cara menghitung perkembangan PAD :

dimana :

$$
\text { perkembangan PAD }=\frac{\mathrm{PADt}-\mathrm{PAD} \mathrm{t}-1}{\mathrm{PADt}-1} \times 100 \%
$$

PAD

$=$ Pendapatan Asli Daerah

PADt

= Pendapatan Asli Daerah tahun sekarang

PADt-1

= Pendapatan Asli Daerah tahun sebelumnya

\section{Rasio Efektivitas PAD}

Kinerja pemerintah Kabupaten Padang Pariaman dalam melakukan pemungutan PAD dapat dikategorikan efektif apabila realisasi penerimaan pajak dan retribusi daerah mencapai target yang telah ditetapkan. Kriteria penilaian efektivitas pengelolaan pajak dan retribusi daerah terhadap penerimaan PAD Kabupaten Padang Pariaman, sesuai dengan Keputusan Menteri Dalam Negeri Nomor 690.900.327 tahun 1996, dapat di lihat pada tabel Klasifikasi Efektifitas Pajak Daerah dan PAD.

\section{Tabel 2}

Klasifikasi Efektivitas Pajak Daerah

\begin{tabular}{|c|c|c|}
\hline No. & Nilai Efektifitas (\%) & Keterangan \\
\hline 1. & $(75$ sd 100$)$ & Sangat Efektif \\
\hline 2. & $(50-75)$ & Efektif \\
\hline 3. & $(25-50)$ & Cukuf Efektif \\
\hline 4. & $(0-25)$ & Kurang Efektif \\
\hline \multicolumn{3}{|c|}{ Sumber $:$ Nick Devas dan Davey }
\end{tabular}

$$
\text { Rasio Efektivitas PAD }=\frac{\text { Realisasi Penerimaan PAD }}{\text { Target PAD }} \times 100 \%
$$

\section{Elastisitas PAD}

Angka elastisitas PAD merupakan salah satu indikator yang digunakan untuk melihat kinerja pengelolaan daerah. Perhitungan terhadap elastisitas PAD ini dilakukan dengan jalan membagi pertumbuhan penerimaan PAD dengan pertumbuhan PDRB. Jika elastisitasnya $>1$, maka indikasi kinerja pengelolaan keuangan daerah sangat baik, dan jika elastisitasnya $<1$ maka kinerja keuangan pengelolaan keuangan tidak baik.

$$
\text { Elastisitas PAD }=\frac{\text { Pertumbuhan Penerimaan PAD }}{\text { Pertumbuhan PDRB }}
$$

\section{Rasio Pajak}

Analisis Rasio Pajak Daerah (Tax Ratio) merupakan salah satu alat atau instrumen yang dijadikan sebagai salah satu alat untuk mengukur kinerja pengelolaan Pajak Daerah. Artinya, semakin besar nilai rasio pajak daerah maka akan semakin baik kinerja pengelolaan pajak daerah tersebut dengan rumusan sebagai berikut : 


\section{Published December 2018}

EKONOMIKAWAN : Jurnal Ilmu Ekonomi dan Studi Pembangunan

ISSN : 1693-7600 (Print), ISSN : 2598-0157 (Online), http://jurnal.umsu.ac.id/index.php/ekawan

$$
R \quad P \quad=\frac{R}{P} \quad \begin{array}{rrr}
P & D & h
\end{array} 100 \%
$$

\section{HASIL DAN PEMBAHASAN}

1. Analisis Peningkatan Rill Pendapatan Asli Daerah di Kabupaten Padang Pariaman

Pendapatan Asli daerah (PAD) dapat didefinisikan sebagai sumber penerimaan yang penguasaan dan pengelolaannya oleh daerah sendiri sebagai daerah otonom. Penguasaan dan pengelolaan komponen-komponen penerimaan PAD tersebut di atur dengan UU No. 22/1999 Pasal 79 dan Pasal 81 serta Undang-Undang No. 34 Tahun 2000 sebagai perubahan dari UU No. 18 Tahun 1997.Berdasarkan UU No. 22 Tahun 1999 maupun UU No. 25 Tahun 1999 sumber penerimaan PAD tersebut terdiri dari :

- Pajak Daerah

- Retribusi Daerah

- Laba BUMD

- Penerimaan Lain-Lain yang sah.

Komponen-komponen penerimaan PAD ini memiliki kontribusi besar terhadap penerimaan PAD adalah Pajak dan Retribusi Daerah. Sedangkan penerimaan dari laba BUMD dan penerimaan lainnya masih relative kecil, meskipun untuk beberapa daerah dapat dianggap cukup potensial untuk dikembangkan. Potensi suatu Pajak ataupun Retribusi dapat diartikan bila jumlah Pajak atau retribusi yang seharusnya diterima oleh Pemda "jika tidak ada objek pajak yang luput dan seluruh wajib pajak/retribusi tersebut membayar kewajibannya sebesar yang ditentukan oleh peraturan yang berlaku."

Tabel 3

Perkembangan PAD di Kabupaten Padang Pariaman

\begin{tabular}{|c|c|}
\hline Tahun & Pendapatan Asli Daerah \\
\hline 2011 & $9,6 \%$ \\
\hline 2012 & $15,5 \%$ \\
\hline 2013 & $36,2 \%$ \\
\hline 2014 & $47,4 \%$ \\
\hline 2015 & $16,3 \%$ \\
\hline
\end{tabular}

Sumber : Laporan Keterangan Pertanggungjawaban (LKPJ)

Pemerintah Daerah Kabupaten Padang Pariaman, 2018.

Pada tabel diatas menunjukkan peningkatan rill PAD Kabupaten Padang Pariaman dari tahun 2011 sampai tahun 2015. Dapat kita lihat pada tabel bahwa PAD di Kabupaten Padang Pariaman naik dari tahun ke tahun yaitu dari tahun 2011 selalu mengalami peningkatan hingga tahun 2014, lalu mengalami penurunan pada tahun 2015. Pada tahun 2011 PAD yaitu sebesar 9,6\%, lalu meningkat pada tahun 2012 sebesar 15,5\%. Pada tahun 2013 meningkat lagi sebesar 36,2\% dan tahun 2014 meningkat sebesar 47,4\%, Kemudian mengalami penurunan sebanyak $31,1 \%$, yang mana PAD nya yaitu hanya sebesar $16,3 \%$. 


\section{Published December 2018}

EKONOMIKAWAN : Jurnal Ilmu Ekonomi dan Studi Pembangunan

ISSN : $1693-7600$ (Print), ISSN : 2598-0157 (Online), http://jurnal.umsu.ac.id/index.php/ekawan

\section{Efektivitas Pengelolaan PAD}

Untuk mengetahui efektivitas pemerimaan PAD Kab. Padang Pariaman tahun 20052011 dapat di lihat dari efektivitas pengelolaan pajak dan retribusi daerah karena pajak dan retribusi merupakan sumber PAD terbesar di Kab. Padang Pariaman, maka data yang dikumpulkan dalam penelitian ini akan dianalisis dengan rasio efektivitas dengan rumus sebagai berikut: ( Halim, 2004).

Kinerja pemerintah Kabupaten Padang Pariaman dalam melakukan pemungutan PAD dapat dikategorikan efektif apabila realisasi penerimaan pajak dan retribusi daerah mencapai target yang telah ditetapkan. Adapun kriteria penilaian efektivitas pengelolaan pajak dan retribusi daerah terhadap penerimaan PAD Kabupaten Padang Pariaman, sesuai dengan Keputusan Menteri Dalam Negeri Nomor 690.900.327 Tahun 1996.

Kinerja pemerintah Kabupaten Padang Pariaman dalam melakukan pemungutan PAD dapat dikategorikan efektif apabila realisasi penerimaan pajak dan retribusi daerah mencapai target yang telah ditetapkan.

Tabel 4

Efektifitas PAD di Kabupaten Padang Pariaman

\begin{tabular}{|c|c|}
\hline Tahun & Efektifitas PAD \\
\hline 2011 & $89 \%$ \\
\hline 2012 & $90 \%$ \\
\hline 2013 & $103 \%$ \\
\hline 2014 & $107 \%$ \\
\hline 2015 & $112 \%$ \\
\hline
\end{tabular}

Sumber : Laporan Keterangan Pertanggungjawaban (LKPJ)

Pemerintah Daerah Kabupaten Padang Pariaman, 2018.

Dari tabel 4 dapat dilihat bahwa dari tahun ke tahun nilai efektifitas PAD secara keseluruhan mendekati $100 \%$ bahkan ada yang melebihi $100 \%$. Jika data tersebut melebihi 100\% maka kinerja pengelolaan PAD dapat dikatakan sangat baik. Pada tahun 2011 efektifitas PAD yaitu sebesar $89 \%$ dan meningkat pada tahun 2012 sebesar $90 \%$, lalu pada tahun 2013 meningkat lagi sebesar 103\%, pada tahun 2014 sebesar 107\% dan pada tahun 2015 efektifitas PAD yaitu sebesar $112 \%$.

\section{Elastisitas PAD}

Tabel 5

Elastisitas PAD di Kabupaten Padang Pariaman

\begin{tabular}{|c|c|}
\hline Tahun & Elastisitas PAD \\
\hline 2011 & 1,63 \\
\hline 2012 & 2,62 \\
\hline 2013 & 5,8 \\
\hline 2014 & 7,9 \\
\hline 2015 & 2,6 \\
\hline
\end{tabular}

Sumber : Laporan Keterangan Pertanggungjawaban (LKPJ)

Pemerintah Daerah Kabupaten Padang Pariaman, 2018 


\section{Published December 2018}

EKONOMIKAWAN : Jurnal Ilmu Ekonomi dan Studi Pembangunan

ISSN : 1693-7600 (Print), ISSN : 2598-0157 (Online), http://jurnal.umsu.ac.Id/Index.php/ekawan

Elastisitas PAD Kabupaten Padang Pariaman berfluktuasi. Akan tetapi secara ratarata angka elastisitasnya adalah lebih dari 1 . Kondisi yang demikian memberikan indikasi bahwa kinerja pengelolaan keuangan daerah terutama penerimaan PAD di Kabupaten Padang Pariaman cukup baik, meskipun masih perlu lebih ditingkatkan di masa yang akan datang.

\section{Rasio Pajak Daerah}

Tabel 6

Rasio Pajak Daerah di Kabupaten Padang Pariaman

\begin{tabular}{|c|c|}
\hline Tahun & Rasio Pajak Daerah \\
\hline 2011 & $15 \%$ \\
\hline 2012 & $15 \%$ \\
\hline 2013 & $15 \%$ \\
\hline 2014 & $15 \%$ \\
\hline 2015 & $16 \%$ \\
\hline
\end{tabular}

Sumber : Laporan Keterangan Pertanggungjawaban (LKPJ)

Pemerintah Daerah Kabupaten Padang Pariaman, 2018

Dari tabel diatas dapat dilihat perkembangan rasio pajak daerah di Kabupaten Padang Pariaman selama periode 2011-2015 tampaknya stabil. Artinya pengelolaan pajak di daerah Kabupaten Padang Pariaman ini sudah stabil.

\section{SIMPULAN}

Berdasarkan pembahasan diatas mengenai kinerja keuangan di Kabupaten Padang Pariaman dapat disimpulkan bahwa kinerja keuangan Kabupaten Padang Pariaman sudah baik dan stabil. Hal tersebut dapat kita lihat dari :

a. Peningkatan riil pendapatan asli daerah di Kabupaten Padang Pariaman, yang mana PAD mengalami kenaikan dari tahun ke tahun walaupun mengalami penurunan pada tahun 2015.

b. Efektifitas pengelolaan PAD dapat dilihat bahwa kinerja pemerintah dalam melakukan pemungutan dan pengelolaan PAD dapat dikatakan sangat baik karena realisasi penerimaan pajak dan retribusi daerah mencapai target yang telah ditetapkan.

c. Elastisitas PAD Kabuaten Padang Pariaman berfluktuasi. Dapat disimpulkan elastisitas PAD bahwa kinerja pengelolaan keuangan daerah terutama penerimaan PAD cukup baik meskipun perlu ditingkatkan lagi dimasa yang akan datang.

d. Pada rasio pajak daerah, dapat kita simpulkan bahwa perkembangan rasio pajak daerah dan pengelolaan pajak di Kabupaten Padang Pariaman sudah stabil.

\section{DAFTAR PUSTAKA}

Abdul Halim. 2007. Akuntansi dan Pengendalian Pengelolaan Keuangan Daerah. Jakarta.

I Gusti Ngurah Suryaadi Mahardika dan Luh Gede Sri Artini. 2012. Analisis Kemendirian Keuangan Daerah Di Era Otonomi Pada Pemerintahan Kabupaten Tabanan. 
Published December 2018

EKONOMIKAWAN : Jurnal IImu Ekonomi dan Studi Pembangunan

ISSN : 1693-7600 (Print), ISSN : 2598-0157 (Online), http://jurnal.umsu.ac.Id/index.php/ekawan

Http://www.negarahukum.com/hukum/pendapatan-asli-daerah.html

Jurnal. Fakultas Ekonomi dan Bisnis Universitas Udayana: Bali.

Mamesa, DJ. 1995. Sistem AkuntansinKeuangan Daerah, PT Gramedia Pustaka, Jakarta

Perwira, Muhammad Yogi. 2014. Analisis Kinerja Keuangan Pada Dinas Pendapatan Pengelolaan Keuangan Dan Aset Daerah Kabupaten Klaten Tahun 2007-2013.

Undang-Undang No. 32 Tahun 2004 tentang Pemerintah Daerah (Pemda).

Undang-Undang No. 33 Tahun 2004 tentang Perimbangan Keuangan antara Pemerintah

Pusat dan Daerah. 